\title{
Morphological Transformation of Gulshan Area: Cause and Effects
}

\author{
Sanjida Ahmed Sinthia, Zishan Fuad Choudhury \\ Department of Architecture, Ahsanullah University of Science and Technology, Dhaka, Bangladesh
}

Email address:

Sinthia.arch@aust.edu (S. A. Sinthia), Zishan.arch@aust.edu (Z. F. Choudhury)

\section{To cite this article:}

Sanjida Ahmed Sinthia, Zishan Fuad Choudhury. Morphological Transformation of Gulshan Area: Cause and Effects. American Journal of Environmental Science and Engineering. Vol. 5, No. 2, 2021, pp. 28-34. doi: 10.11648/j.ajese.20210502.12

Received: November 26, 2020; Accepted: December 22, 2020; Published: May 8, 2021

\begin{abstract}
Cities are vigorous in nature. It has a habit of grow and change depending on its interface among diverse social, economic and political environment. It is the common nature of cities to embrace changes with time which create entirely new kinds of fabric and with this the basics of urban form have changed a lot. The city of Dhaka has its long history since 17th century which had experienced dramatic changes over the last few decades. Over the time, Plots, low lands and water body and open spaces have been transformed into different developed areas. It has been grown in a natural way without any rigid planning proposal although it has some parts deliberately designed by the city authority for residential purpose. As a result, the growing city seems to have exhibited a series of organic and formal spatial pattern at the same time. Furthermore, to meet the demand of increasing residents the city has stretched in diverse parts, shifted its core and formed new urban activities. As a result, single family house plot has been transformed into multi-layer residential unit and in some parts of the city the residential plots have been converted into commercial purpose which is the consequences of the transformation process. Logically, it has become a vital to articulate Detailed Area Plan for Dhaka and this bold decision by RAJUK may prove to be constructive for the city in the long run. Therefore, this paper aims to investigate the cause and effect of social, functional and spatial changes of the residential area of Gulshan area, Dhaka due to morphological transformation of plot and land use pattern for various reasons. As well as to explore how the development control planning organizations involvement can mitigate the situations.
\end{abstract}

Keywords: Morphological Transformation, Cause and Effect, Residential Area, Plot Division, Land Use Pattern, City Authority

\section{Introduction}

From pre-historic era to modern period cities are the most complex and prime objectives that human being formed. With a few exceptions, they came into existence not through creation, but through the process of evolution and revolution [4]. Above all, the city is a social product created out of the demands of everyday use and the social struggles of urban inhabitants [5]. Dhaka, the capital of Bangladesh, has started its journey from pre-Mughal period (1205-1610) to Pakistan period (1947 to 1971), the city has testified different phases. In these four hundred years, the city expands from a feudal trading town to a large metropolis. This rapid growth makes the city practically, well cabinet of every urban problem imaginable. This process of urbanization converted the open space, wetland into built up areas and created formal and informal settlements for the citizens. In this chaotic situation part of cities have been purposely developed as a residential area to deliver the resident with community facilities specially for high class inhabitants. In such planned scheme, the infrastructure is constructed following conscious design by the govt. authority and the land is subdivided into residential plot with necessary infrastructure and then delivered to the user [6]. However, in the course of time the formal residential part such as Dhanmondi, Gulshan, Banani which actually owned by the elite class of the city are converted into commercial uses and has been gone through plot division process. Obviously, this process has a great impact on the social, economic and functional dynamics of the area. To understand these changes, the transformation of the spatial structure that shapes the cities with its ages of urban evolution seems necessary to analyze. 


\section{The Process of Morphological Transformation}

Urban morphology is the study of the city as human habitat. Ethnographer Lévi-Strauss [18] described the city as 'the most complex of human inventions, at the convergence of nature and artifact'. The evaluation of the city, its transformation and classifying its diverse components are the major interest area of urban morphologist. The growth of the city shaped by the social, economic and cultural traditions which drives over time but also the activities of its individuals and ethnic group mold the characteristics of the place. Though, the emphasis of the urban morphologist was always on the tangible features of social, cultural, economic and physical outcomes which ground and mold our cities. Buildings, gardens, streets, parks, and monuments, are among the main elements of morphological analysis which are constantly used and hence transformed through time. They also exist in a state of tight and dynamic interrelationship: built structures shaping and being shaped by the open spaces around them, public streets serving and being used by private land owners along them [9].

The morphological method searches for to characterize, measure and analyses the basic element of urban form and process of edifice city because the approach focusses on the built space, open space, and so on [17]. Urban morphology is an analytical method that explores constitution of urban form, their formation, and transformation, classification of urban space and form by analogies and homologies. To understand the relationships between these attributes urban morphology established three classes, which contain the basic element of urban form [11]. However, from above discussion it is clear that there are three distinct elements of urban forms: buildings and their related open space, plot or lot and street. These urban forms characterized through its shape and density as well as its definite and probable use over time. The study shows that the underlying features of its elements illustrates the timeline of urbanization but also the socio-economic environment of that time of building development. According to the theory of Conzen, an area can be distinguished from other surroundings in four levels of classified structure- 1. The basic historical elements and development with adaptive process; 2 . First settlement areas and old development characterized by transformative processes; 3. Combination of old and new development areas which involves the process of repletion; and 4. New development areas represented by additive processes. Each layer signifies the basics characteristics of historical time layer [23].

Over time, these elements are either used differently - for example, by different social classes - transformed physically, eliminated or replaced by new forms. The rate of change in either the function or the form of the cells varies from city to city, but also generally fits into cycles related to the economy and culture. Building and transformation cycles are important processes to explore for city planning and real estate development purposes, yet are rarely studied in contemporary cities.

\section{Study Area}

On the basis of size, income group, construction period, Gulshan area has been chosen as the study area in order to evaluate the morphological transformation of planned area. This area was designated for high class residents after the partition of Pakistan under a planning division created by the East Bengal government in 1948 due to the need of civic facilities and automobiles.

\section{Morphological Analysis of Study Area}

\subsection{Locational Aspects}

In the Structure Plan of Dhaka city, the Residential Area of Gulshan is located in SPZ-6 (Strategic Planning Zone) \& it is under ward 19 and ward 20 of DCC (Dhaka North City Corporation). It lies in $23^{\circ} 47$ 'to $23^{\circ} 48^{\prime} \mathrm{N}$ latitude and $90^{\circ} 24^{\prime}$ 29" E Longitude [7]. The total Gulshan Residential area was bounded by Gulshan Lake in the east, west, Tejgaon industrial area in the south, and Cantonment area on the north. The lake besides Gulshan and Baridhara is well preserved than the lake on the western peripheral of Gulshan. The lake side development and lake itself are now in development process on the western side. Though, a large part of the western lake belongs to private possession with slum settings and other encroachment. Most of that part of the lake are infringed by allotters which is the most critical problem on the western fringe of Gulshan.

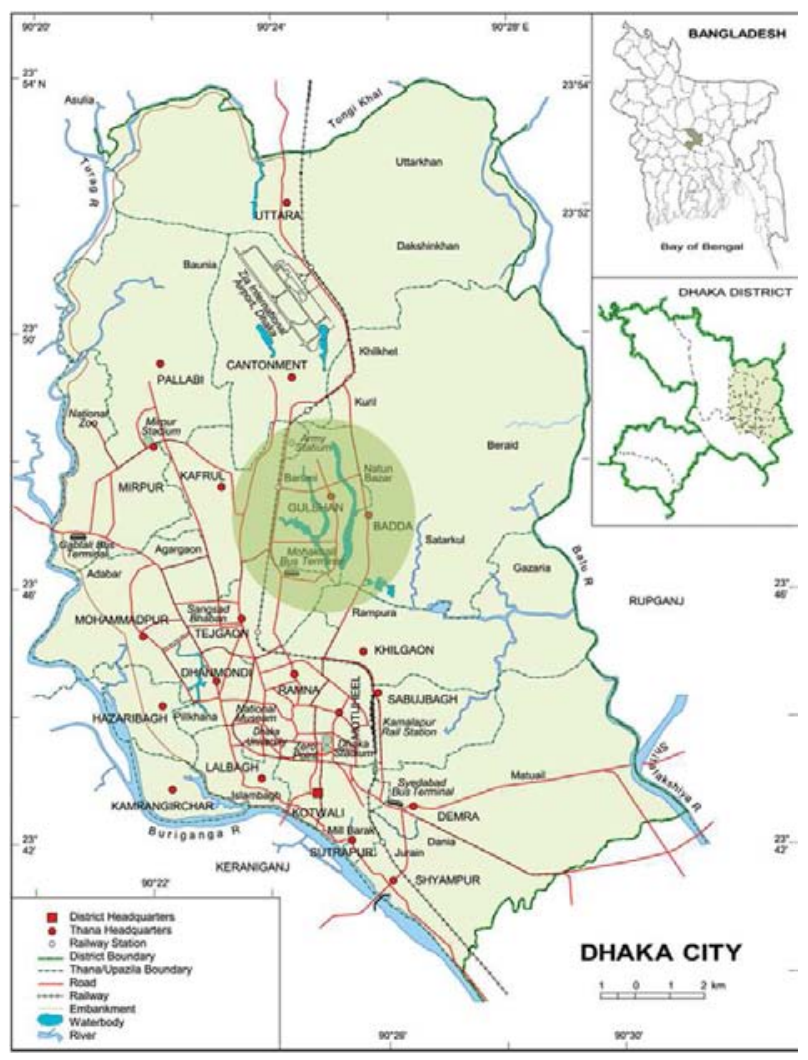

Figure 1. Location and administrative map of Dhaka City [19]. 


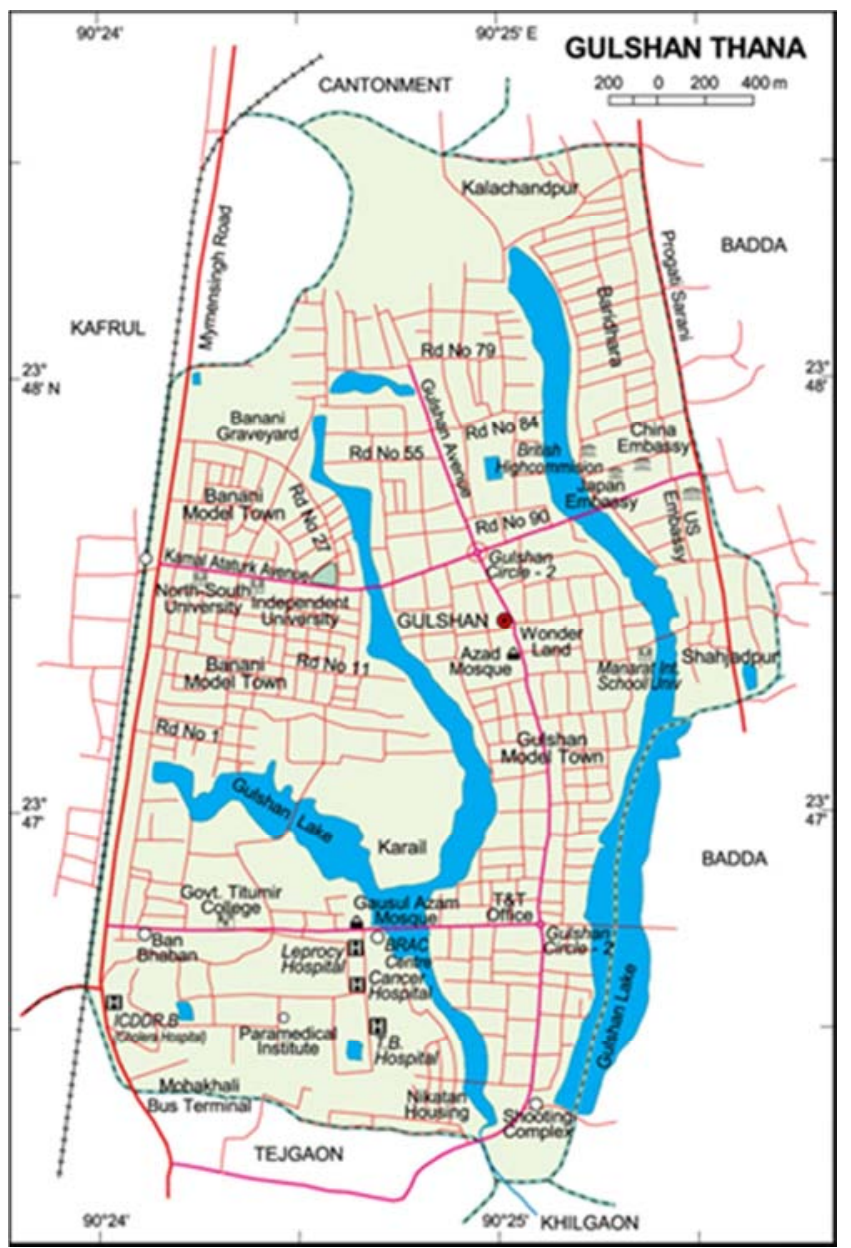

Figure 2. Map of Gulshan Thana [22].

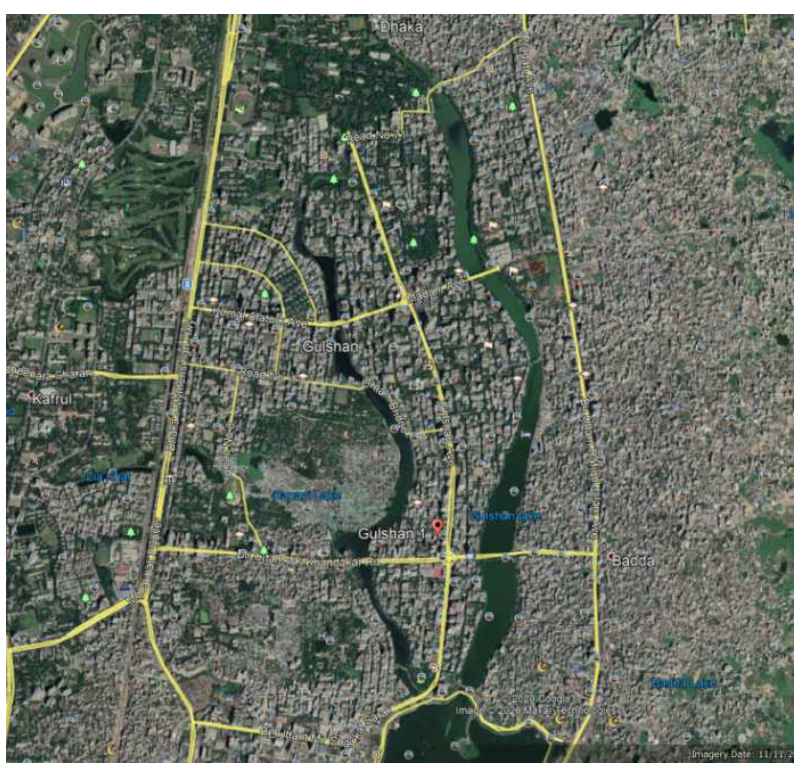

Figure 3. Google Earth Map of Gulshan Area 11/11/2020.

\subsection{Demographic Analysis}

The SPZ 6 has two distinct parts: The developed planned potion of this zone is the place of occupancy of rich and the elite people, while the organic eastern part is occupied by middle-income and low-income population.

Table 1. Decadal growth of population: 1974-2000, [1].

\begin{tabular}{ll}
\hline Year & Population \\
\hline $1974-1981$ & 39.7 \\
$1981-1991$ & 61.6 \\
$1991-2001$ & $-(32.3)$ \\
\hline
\end{tabular}

Table 2. Demographic structure of Gulshan Thana, [1].

\begin{tabular}{llll}
\hline Year & $\mathbf{1 9 9 1}$ & $\mathbf{2 0 0 1}$ & $\mathbf{2 0 1 1}$ \\
\hline Area in sq. km. & 53.59 & 10.29 & 8.7 \\
Population & 281,337 & 190,590 & 253,050 \\
House hold size & 5.5 & 4.3 & 4.4 \\
Density in sq. km. & 5,250 & 18,522 & 29,086 \\
\hline
\end{tabular}

\subsection{Planning Aspects}

The area of Gulshan was developed as a rural settlement with plots in different size and shape and without proper road network under Bhola Mouza. At that time the government acquired the area and started to develop Gulshan as a clean and organized planned residential neighborhood, free from traffic hazards and nuisance under DIT (RAJUK) in 1959 [2]. The area was initiated as a planned model town in 1961 with its own Municipal Corporation originally destined for offices and assemblies of diplomatic missions, as well as high class residences [14]. Later, in 1982, Gulshan was abolished and in 1984, Gulshan along with Mirpur municipality was captivated into Dhaka [8]. The original Master Plan proposed provision of amenities and facilities for their high-class residents like retail markets or shopping centers, schools and mosques in the planned residential districts. Any other nonresidential use was officially banned [10]. At that time another two major project 'Uttara Model Town, 1965' and 'Baridhara Residential Area 1962' was proposed [13]. However, after 1971 consecutive government unsuccessful to afford appropriate consideration to the planning issues and thus misguided urban growth. Moreover, the rapid political and socio-economic changes caused major violations of land use recommendations [15].

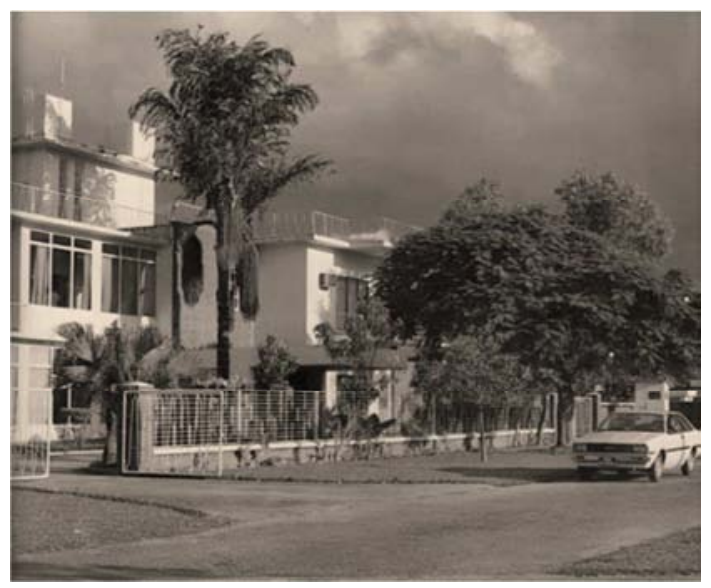

Figure 4. Gulshan area old Photograph early 1980s. 


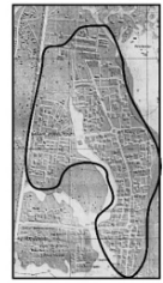

1973

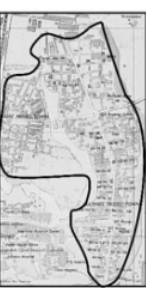

1987

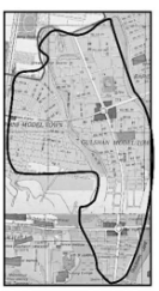

1995

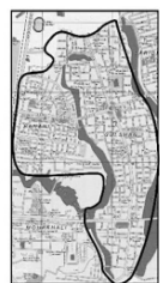

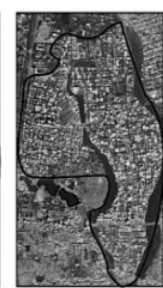

2007
Figure 5. Transformation of Gulshan area from 1973 to 2007, [20].

\subsection{Land Acquisition and Planning}

The Gulshan area was developed especially for high ranked government and non-government officials. As a result, the plot size was large with low density. Total 290 hectors land was acquired to develop the Gulshan residential area [10]. At the initial planning phase, the Gulshan area was settled from Tejgaon to Gulshan 1 circle which included 715-acre area with large plot size and regular road network [16]. After liberation, the increased demands for high class residential initiate the extended formal layout for Northern territory of Gulshan area. The layout map shows the blocks were designed in a simple rectilinear grid pattern of varied size oriented with their long sides both on east- west and north -south direction surrounded by the arterial and access roads. The area was developed like a finger pattern cluster with a series of dead end (culls-de sac) in which building are arranged around a short access street. Besides the Gulshan 1 and Gulshan 2 circles the plots were designed in a radial pattern. The total number of plot size in 1979 was 1680 which increased to 1879 in 2002 and 2356 in 2005 [12].

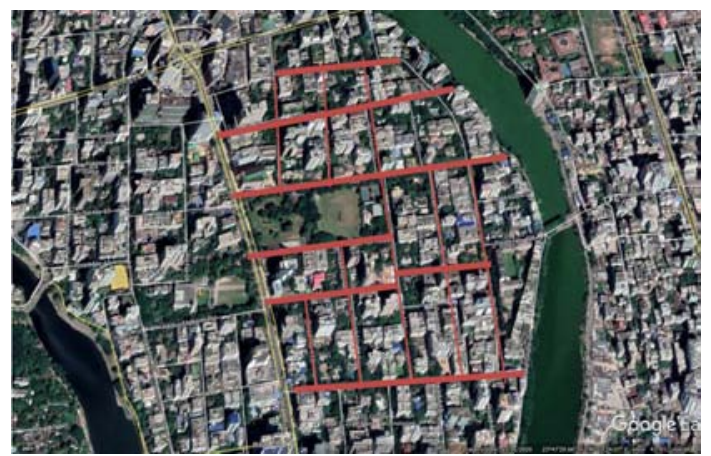

Figure 6. Google Earth Map of Gulshan Area showing grid Iron pattern $11 / 11 / 2020$

\subsection{Different Phases of Plot Transformation}

The first phase dated $1973-1985$, development of Gulshan residential area shows blocks were planned in a grid-iron pattern with varying size between $1440 \mathrm{sqm}$ to $2160 \mathrm{sqm}$. In second phase dated 1997 to 2002 illustrate that some large blocks were fragmented with revised plot division. During this phase the plot were subdivided to distribute among different successors of the original owner.

There is a radical change in phase three (2000-2005) in comparison to previous plots. In this phase, the successive divisions of plots were increased in alarming rate. Some plots which were sub-divided in the previous phase were seen to be merged again in this phase [10]. Therefore, the process of physical transformation continued to exist together with the transformation of the functional aspect. In this phase (2005-2010), the sub divided land demand high value for the land due to commercial development. The lands attached with the main arterial road were more open to accommodate high rise buildings with maximum land coverage [10]. At present day, the plot alongside the Gulshan avenue is only for commercial development with highly speculative price.
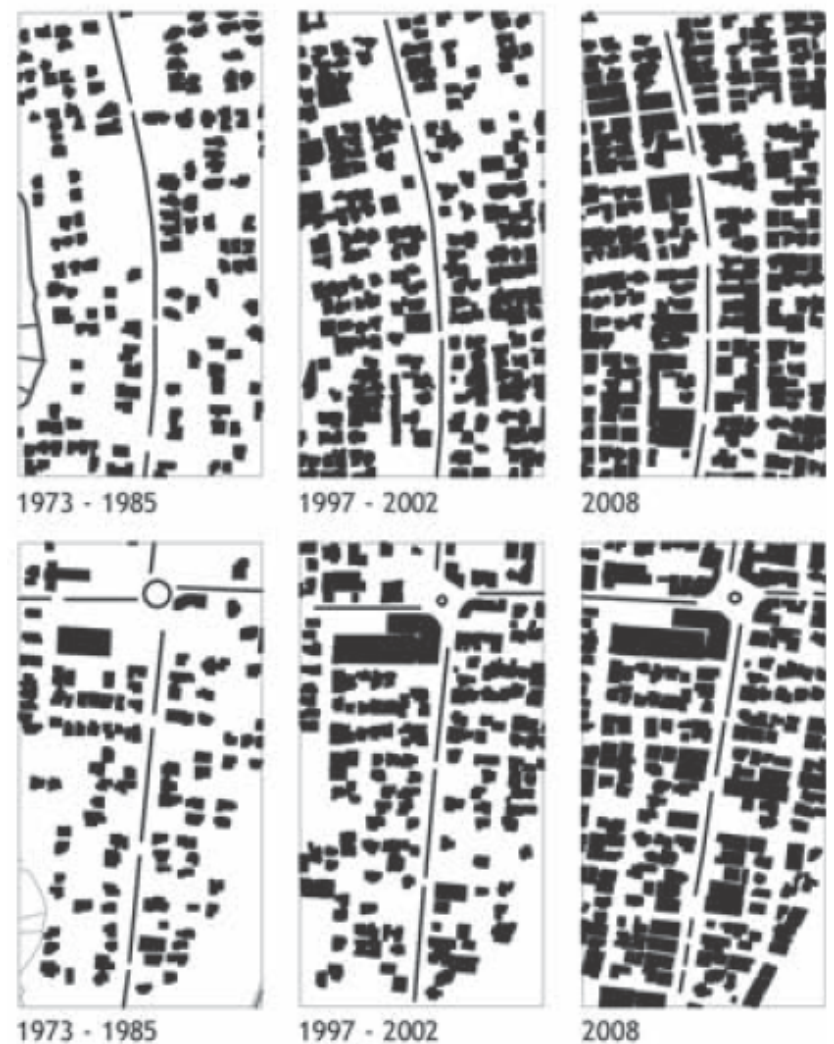

Figure 7. Ground Map of Gulshan Area [21]

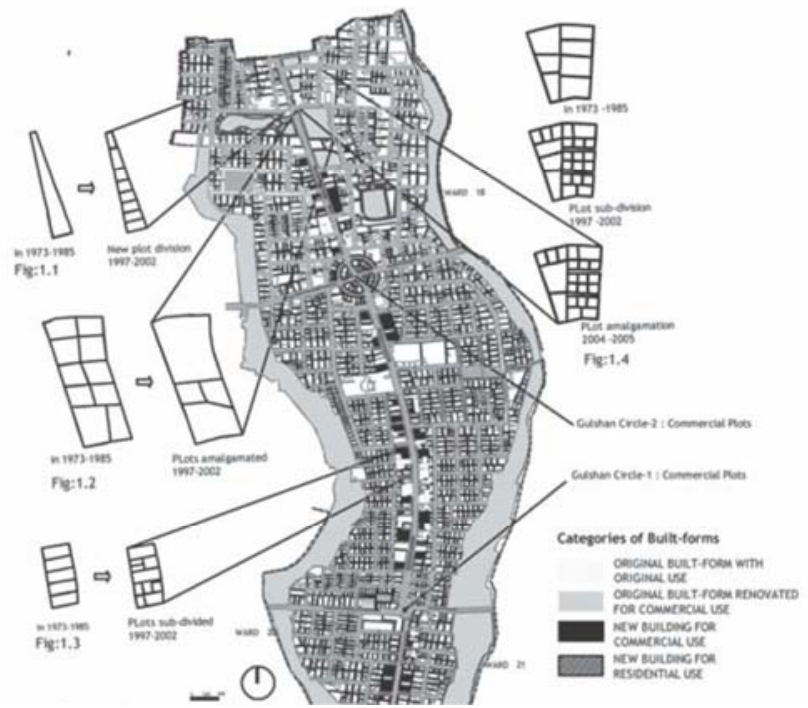

Figure 8. Land use maps with plots, Gulshan residential area, 2008 [21]. 


\section{Causes and Effects of Transformation}

The Gulshan Avenue has experienced different phases and building law throughout its development. In the process of time, the individual single-family houses of the early 1970s that positioned distant from each other in Gulshan area have disappeared because of the commercial thriving; to the point of old residents claiming it are not a residential area any more [14]. These changes occur mainly due to beginning of real-estate business as a major economic activity. With the growth of Dhaka city, changes in the economic environment brought significant changes in the urban land uses in different part of the city which gradually invade the large residential plots of Gulshan area into commercial use. Although the landlord plays a significant role due to the multiple number of successors for sub division of land and land use pattern of the area. Profit motivated people subdivided their plot for commercial use along the road that also increase the total number of plots. Not only that some plots are newly designed by the authority time to time by filling the land of the lake side. As an effect from 1990, pressure for land use conversion particularly along the avenue started develop. A revision of building rule for the plots along Gulshan Avenue was introduced by RAJUK in 2000 [10]. Under this rule, residential plots along the avenue were given permission to convert for commercial use with a conversion fee of $25 \%$ of the prevailing land value. As a result, the low-density characteristics of this area which was planned in initial development phase has transformed into high density, high-rise residential and commercial area. This physical change of the built environment is additionally allied with the changes in land use, together with the economic growth of the city. The land use conversion which started in the early 1990's has now gone beyond control, affecting the density, volume and overall quality other residential environment [7].

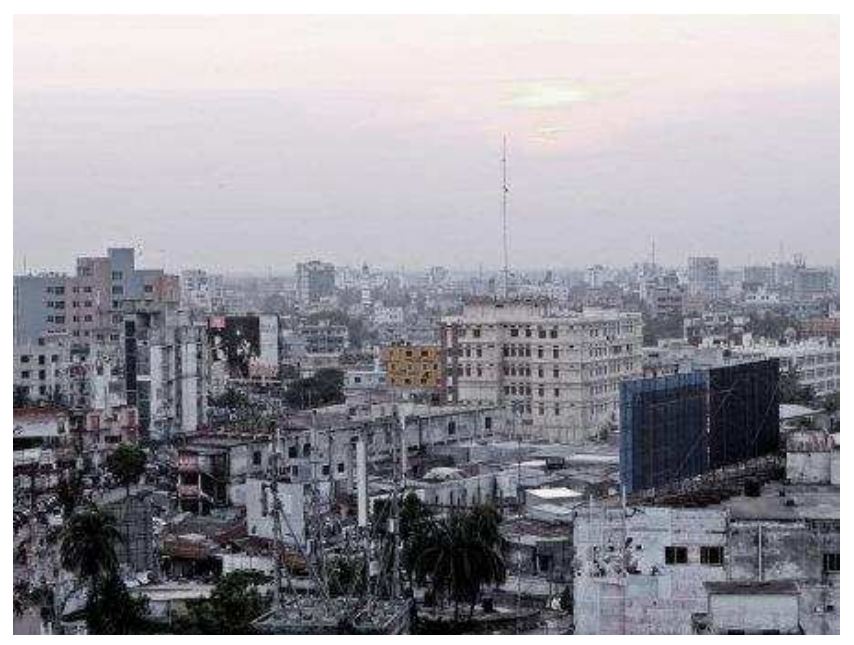

Figure 9. Recent photograph of Gulshan area.

\section{Existing Land Use Pattern}

As Gulshan is well connected with the other part of the city, it attracted private organization, Multinational Companies and
NGO to establish their office here. As a result, the commercial activities are growing significantly, which is altering the character of the residential area. According to the Dhaka City Corporation (DCC) land use map 2005, there are about 33 foreign embassies, 35 famous governments and nongovernment offices are spread all over the area. Among them, there are many international and multinational offices. Other than the land use conversion law there are also an allotment terms and condition law for residential structure. According to the law, an allot tee must built a residential structure on the allotted plot within a period of four years of allotment and has to use it for residential purpose only. Though, a large number of structures in Gulshan Residential area are used by non-residential purpose which is approximately $50 \%$ of the area which is a violation of land allocation agreement [3]. The haphazard use of conversion law and malpractice of rules and regulation transformed the morphological character of the Gulshan residential area. In this process the percentages of non -residential use of the plot are gradually over time, almost $47.03 \%$ of the plots are used for nonresidential purpose [2]. Residential buildings are generally located at the inner part of the area. Most of the commercial activities: markets, shopping plaza, recreational facilities, and service-oriented office are located along the main access crossing along north south and east west of the area. That means all the Primary \& Secondary Arterial road (Gulshan Avenue, North Gulshan Avenue and South Gulshan Avenue) are invaded by non-residential activities. Besides there is a significant number of educational institutions, small scale commercial activities include hotel and restaurant, community facilities, recreational facilities, different kind of service facilities etc. are found along the residential uses building on the collector and access road which depict a mixed nature of urban fabric. Besides, the powerful rich are buying privately owned lands lying in the lake and constructing the high-rise structures avoiding the existing rules. Recently, Government has taken few steps and development planning process to preserved the open spaces and parks in Gulshan area which is under threat due to poor maintenance. Overall, the government should apply effective policies to control the illegal uses, transformation and protect the lake and parks.

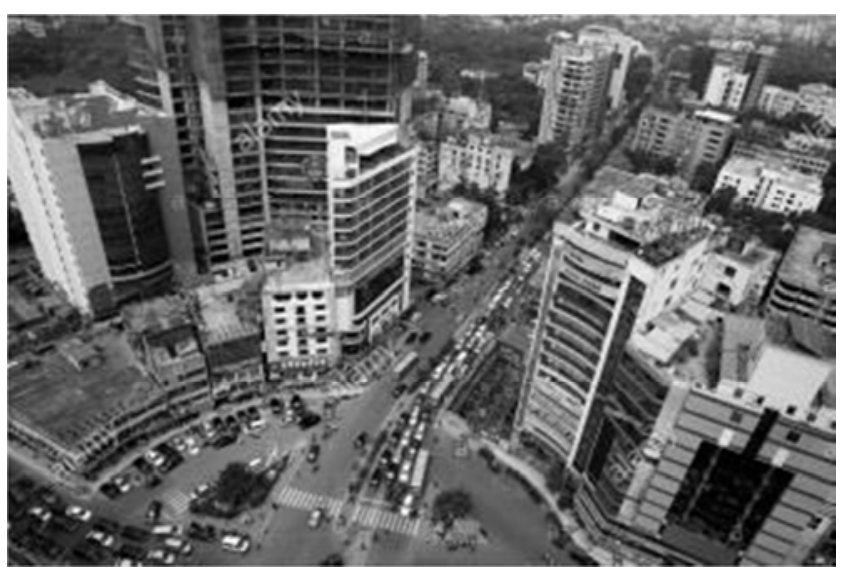

Figure 10. Converted Commercial plot along the main road. 


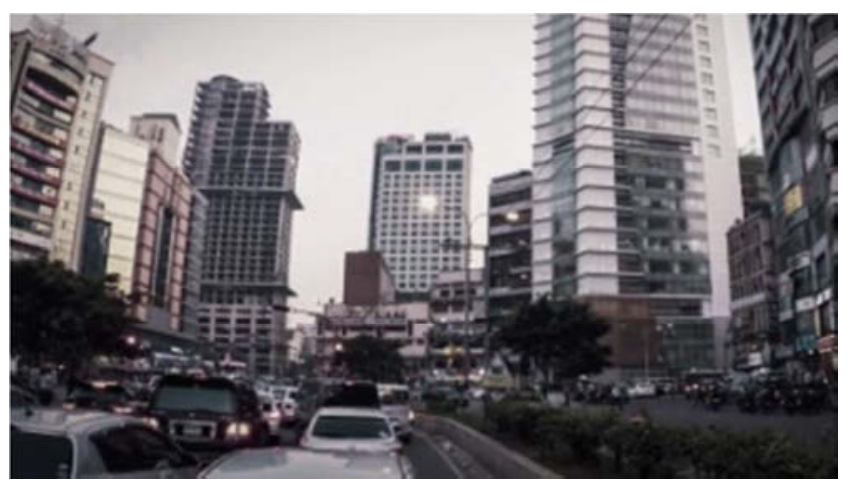

Figure 11. Changed Land Use pattern of Gulshan area.

\section{Proposed Land Use Zoning by DAP}

The major concern of the Gulshan area is the transformation of residential uses in nonresidential uses. This rapid invasion causes high rent of the buildings and instigates many house owners to rent their houses for nonresidential purpose to earn higher profit violating Building Construction Rules. This brief analytical Study has exposed that the commercial activities along with other economic events are on fast growth in this area which is resulting in penetration of non-residential uses in residential areas. This functional transformation and growing demands for commercial activities generate formulation of new policy proposed by DAP, DMDP of location 4 which is mixed use of land on both sides of Gulshan Avenue and Kamal Ataturk Avenue up to the depth of one plot only [3]. Any other activities other than commercial use which include shops, commercial establishments and offices, company offices, location of foreign missions etc. should not be allowed to locate in the mixed-use areas of Gulshan and Banani [3]. Moreover, the DAP proposed new commercial land with mixed uses and lakeside development to create green and open space for the residents. The table shows that the built-up area of DAP-1 proposed to be remain residential area other than the selected part which can be use as commercial. It means that as development control authority, RAJUK, will have to take a strong drive to evict unauthorized non-residential uses in the residential parts of the area.

\begin{tabular}{|c|c|c|c|c|c|}
\hline \multirow{2}{*}{$\begin{array}{l}\text { Landuse } \\
\text { Category }\end{array}$} & \multicolumn{3}{|c|}{ Area in Acre } & \multirow{2}{*}{$\begin{array}{l}\text { \% of } \\
\text { Total } \\
\text { Land }\end{array}$} & \multirow[b]{2}{*}{ Comments } \\
\hline & Existing & $\begin{array}{l}\text { Proposed } \\
\text { (Additional) }\end{array}$ & $\begin{array}{l}\text { Recommended } \\
\text { Total }\end{array}$ & & \\
\hline Residential & 443.14 & -35.84 & 407.30 & 41.31 & $\begin{array}{l}\text { Vacant lands have been } \\
\text { added to residential and some } \\
\text { residential land has been } \\
\text { converted to mixed use. }\end{array}$ \\
\hline Commercial & 22.63 & +5.59 & 28.25 & 2.87 & $\begin{array}{l}\text { Some residential plots/ land } \\
\text { have been proposed for } \\
\text { commercial use }\end{array}$ \\
\hline Mixed & 6.88 & +77.49 & 84.04 & 8.52 & $\begin{array}{l}\text { Vacant land and land from } \\
\text { residential use have been } \\
\text { proposed for mixed use }\end{array}$ \\
\hline Administrative & 23.90 & -3.00 & 20.90 & 2.12 & - \\
\hline $\begin{array}{l}\text { Institutional / } \\
\text { Social Service }\end{array}$ & 11.19 & - & 11.19 & 1.13 & - \\
\hline Urban Service & 2.14 & - & 2.14 & 0.22 & - \\
\hline Diplomatic & 30.20 & - & 30.20 & 3.06 & - \\
\hline $\begin{array}{l}\text { Open DAPce- } \\
\text { Park and Play } \\
\text { Field }\end{array}$ & 19.37 & +8.80 & 28.17 & 2.87 & $\begin{array}{l}\text { New parks and recreational } \\
\text { green DAPces have proposed } \\
\text { from lakeside lands. }\end{array}$ \\
\hline Recreational & 0.20 & - & 0.20 & 0.02 & - \\
\hline Road & 229.50 & +86.46 & 315.96 & 32.04 & $\begin{array}{l}\text { New roads have been } \\
\text { proposed. }\end{array}$ \\
\hline $\begin{array}{l}\text { Water body/ } \\
\text { Lake }\end{array}$ & 89.18 & -31.53 & 57.65 & 5.85 & $\begin{array}{l}\text { Parts of water bodies have } \\
\text { been proposed for new road } \\
\text { construction. }\end{array}$ \\
\hline Unused/Vacant & 107.23 & -107.23 & 00.00 & 0.0 & $\begin{array}{l}\text { Vacant lands have been } \\
\text { proposed for other uses. }\end{array}$ \\
\hline Total & 986.00 & - & 986.00 & 100.00 & - \\
\hline
\end{tabular}

Figure 12. Existing and proposed land use of DAP zone 01, [7].

The Changes in land use pattern is very common phenomenon throughout the history of development process of any city. In developing country where land use policy is not very strong is very difficult to control the over the land use and gentrification. The Master Plan for Dhaka city was formulated in 1959 and approved in 1960; after that there is no new land use plan with these rapid growths. The Ministry of Housing and Public works formulated the DMDP Structure Plan (1995-2015) which lacks the detail land use plan for the entire
SPZs. There is no interim planning policy to control land use in the development area. As a result, unpredictable land uses are mounting almost everywhere in the city. This is affecting the physical environment, specially, the residential areas. The Government should prepare in advance the land use plan under Detailed Area Planning Project and strictly enforce the land use provisions planning through continuous monitoring and disciplinary actions for violations of the area which is the only way to avoid this inclination. After the Detailed Area 
Plan is approved (which is now in under process, New DAP, 2020), all planning permissions in the area should be in accordance with the provisions of the land use plan. RAJUK has given the full authority within its jurisdiction to control over the building construction under the act of Section 3 (A) of Building Construction Rules, 2006. The DAP has provided the list of activity which can be performed in the residential areas that are being transformed into non-residential uses and designated as mixed-use areas. This step would ease accord of non-residential building plans, particularly, in plots with frontage of major road. DAP provided detail guidelines of Urban Area Plan which should be carefully studied before giving approval to industrial and processing establishments. The authority should refrain to permit of those industries which pollute environment particularly besides the residential areas. [3].

\section{Conclusion}

The changing economy and the continual urban process are the fundamental of the transformation of the Gulshan area. With the various dynamic forces of urban development shifted the residential character of this area into commercial district. This pattern of morphological transformation can be expected to continue in the future as well. These are the cause and effect of ineffective development control planning organizations and failed to address the demand and supply of buildable and livable urban land. It is now time to properly implement the DMDP plan to address the development problems of the city that covers the growth area issues. A realistic and adequately accurate assessment of the existing situation was a pre-condition to form an effective basis for this planning effort. Community involvement by building awareness could play a positive role for preventing violation of land use. This community cohesiveness may ensure future livable Dhaka city for next generation.

\section{References}

[1] Bangladesh Bureau of Statistics. Population Census 2011, National Report (Provisional). Ministry of Planning, Dhaka: Bangladesh, (BBS): Feb 2007, 2011.

[2] Afsana D. Land use Conversion in Dhaka: Impact of Residential Neighborhood" Paper presented in 18 CAA Conference on Society Architects and immerging Issues, Dhaka.

[3] Draft Dhaka Structure Plan, Detailed Area plan, 2016-2035.

[4] Hillier, Bill, and Alan Penn. "Dense Civilizations: The Shape of Cities in the 21st Century." Applied Energy, vol. 43, no. 13, Jan. 1992, pp. 41-66, 10.1016/0306-2619(92)90073-k.

[5] Khan, Nayma (2008) "Study of Morphological Transformation in the Planned Residential Areas of Dhaka City"; Unpublished MSe. Thesis; Department of Architecture: Bangladesh University of Engineering and Technology', Dhaka.

[6] Nilufar, Farida (1997) "The Spatial and Social Structuring of Local Area in Dhaka City - A Morphological Study of the
Urban Grid with reference to Neighborhood Character within Naturally Grown Areas" Unpublished Doctoral Dissertation; Unit for Advance Architectural Studies, The Berlet School of Graduate Studies, University College London, University of London.

[7] Rajdhani Unnayan Kartipakkha (RAJUK), 1001; Dhaka Metropolitan Development Plan (DMDP) Location 4, Ministry of Housing Ltd. Public Works, Government of Peoples Republic of Bangladesh.

[8] Ghafur, Shayer (2006). The Future of Gulshan South Park" Daily Star, April, 2006.

[9] Moudon, A. V (1997) "Urban Morphology as an Emerging Interdisciplinary Field"; International Seminar on Urban Form; Urban Morphology Journal, VoL 1.

[10] Zereen, Nuzhat (2009) “A Study of the Morphological Transformation and the emerged Built-forms along Gulshan Avenue, Dhaka. Masters of Architecture, Department of Architecture, BUET, January 2009.

[11] Whitehand, J. W. R. "Book Review: An Introduction to Urban Historical Geography." Progress in Human Geography, vol. 8, no. 4, Dec. 1984, pp. 579-580, 10.1177/030913258400800413. Accessed 15 July 2020.

[12] Nabi M. ASM., Khandokar F., Kamruzzaman K. "Apartment housing in high class residential area of Dhaka city: A case study of Dhanmondi, Gulshan and Baridhara" Jahangirnagar Planning Review, voI. 2, Dhaka: Jahangirnagar University.

[13] Chowdhury A. M., Faruqui Shabnam, "Physical Growth of Dhaka", Dhaka past Present Future. Dhaka: The Asiatic Society of Bangladesh.

[14] Ahmed B., Hasan R., Maniruzzaman K. M. Morphological Change of Dhaka City over a Period of 55 Years: A Case Study of Two Wards.

[15] N Islam, "Dhaka in 2025 A. D." International Symposium on Dhaka- Past Present Future 'The Asiatic Society of Bangladesh. Dhaka.

[16] Huq A. T. M. Zahirul,"Transport Planning for Dhaka City" Dhaka - Past, Present, Future, Dhaka: The Asiatic Society of Bangladesh.

[17] Conzen, M. P (1990) "Town Plan Analysis in an American Setting"; in slater T. R, ed. The built form of Western cities, Leicester University Press, London.

[18] Levi Strauss, C. (1995), Tristes, Tropiques (Terre Humaine, Paris).

[19] Swapan M. S. H, Zamman A., Ahsan T., "Transforming Urban Dichotomies and Challenges of South Asian Megacities: Rethinking Sustainable Growth of Dhaka, Bangladesh", Urban Science, MDPI, 2017, 1, 31.

[20] Ahmed B., Hasan R., Maniruzzaman K. M., "Urban Morphological Change Analysisof Dhaka City, Bangladesh, Using Space Syntax", ISPRS, Int. J. Geo-Inf. 2014, 3, 1412-1444, ISSN 2220-9964.

[21] Nilufar, F., Zereen, N., "Process of Morphological transformation and the Emerging Pattern of Built Form along Gulshan Avenue in Dhaka", Cities in Transformation Research and Design, Vol-1, ILPOLIGRAFO.

[22] Maps of Bangladesh: Gulshan Thana (bdmaps.blogspot.com). 